\title{
The use of biological methods based on macroinvertebrates to an Iberian stream (Central Portugal) receiving a paper mill effluent
}

\author{
W. V. Blijswijk, C.N. Coimbra* \& M.A.S. Graça \\ IMAR - Instituto do Mar, Centro Interdisciplinar de Coimbra, Departamento de Zoologia, Universidade de \\ Coimbra, 3004-517, Coimbra, Portugal \\ *Correspondence author: ncoimbra@ci.uc.pt
}

\begin{abstract}
The impact of a paper mill effluent on the macroinvertebrate communities of an Iberian stream located in Central Portugal was assessed. We used a modification of the BMWP' and BBI indices, diversity measurements (number of taxa and 1-Simpson index) and multivariate methods (cluster, MDS and CA analyses). All techniques indicated a strong impact in the vicinity of the effluent output with a slow recovery ca 4 - $7 \mathrm{~km}$ downstream. Multivariate analyses clearly segregated reference (upstream) sites from strongly and moderately impacted sites. Analysis of similarity (ANOSIM) showed also significant differences among groups of sites defined by MDS analysis $(\mathrm{P}<0.001)$. There was a significant correlation $(\mathrm{P}<0.001)$ between $\mathrm{BBI}$ and BMWP' indices and the first CA axis (pollution gradient) which suggests that both indices were suitable for water quality assessment in this stream and pollution type. However, we recommend the use of the BMWP' index due to the lesser needs in terms of taxonomic expertises.
\end{abstract}

Keywords: biological methods, biotic indices, Iberian Peninsula, macroinvertebrates, water quality.

\section{RESUMEN}

Se ha evaluado el impacto producido por el vertido de una fábrica de papel sobre las comunidades de macroinvertebrados de un arroyo Ibérico localizado en el Centro de Portugal. Se utilizó una modificación de los índices BMWP'y BBI, medidas de diversidad (número de taxones e índice 1-Simpson) y métodos multivariantes (cluster, MDS y análisis CA). Todas las técnicas indicaron un fuerte impacto en las inmediaciones del vertido con una lenta recuperación a lo largo de 4 - $7 \mathrm{~km}$. río abajo. Los análisis multivariantes segregaron claramente las estaciones de referencia (cabecera) de aquellas fuertemente o moderadamente impactadas. El análisis de similitud (ANOSIM) mostró también diferencias significativas entre los grupos de estaciones definidos por el análisis $M D S(P<0.001)$. Hubo una correlación significativa $(P<0.001)$ entre los índices BBI y BMWP', y el primer eje CA (gradiente de contaminación), lo que sugiere que ambos índices fueron adecuados para evaluar la calidad del agua en este arroyo y para este tipo de contaminantes. No obstante, se recomienda el uso del indice BMWP'por sus menores exigencias en lo que respecta a los expertos en taxonomía.

Palabras clave: métodos biológicos, índices bióticos, Península Ibérica, macroinvertebrados, calidad del agua.

\section{INTRODUCTION}

Biotic indices are numerical expressions used to assess water quality, based on the presence and, in many cases, the diversity of taxa with known environmental-pollution tolerances. Macroinvertebrates are some of the most popular indicators used in biotic indices and other biological methods due mainly to their relative large size, low cost and ease of sampling, relatively easy identification and relatively long life cycles
(Hellawell, 1986; Metcalfe, 1989; MetcalfeSmith, 1996). Low mobility and long life cycles ensure that the presence of a given taxon at the sampling time reflects past conditions.

Biotic indices have been applied in many European Union countries to assess water quality. One of the first biotic indices using exclusively invertebrates was applied in the River Trent basin, U.K. (TBI - Woodiwiss, 1964), but other followed and are nowadays used all over Europe: the Belgian Biotic Index (BBI - De 
Pauw \& Vanhooren, 1983) in Belgium, the Indice Biologique de Qualitè Genèrale (IBG Vernaux et al., 1982) in France, the Biological Monitoring Working Party score (BMWP Armitage et al., 1983) in United Kingdom, and its variant, the BMWP' (Alba-Tercedor \& Sánchz-Ortega 1988, Alba-Tercedor, 1996) in Spain. Some of these indices have been applied in the Iberian Peninsula, i.e., outside the area for which they were developed, some times with small adaptations. Examples for Spain were reported by Garcia-Criado et al. (1999), Zamora-Muñoz \& Alba-Tercedor (1996).

There is nowadays a general consensus in the European Union for the necessity of the application of biological methods in combination with geomorphological, physical, and chemical parameters for routine water quality assessments (Water Framework Directive 2000/60/EC). For countries such as Portugal with no tradition in the use of biological methods, two strategies can be used in face of the E.U. policy: (a) develop new biological metrics taking into account the local natural environmental conditions or (b) alternatively, the application of indices developed for other areas can be tested with the Portuguese stream systems.

In Portugal, several researchers have applied biotic indices to assess water quality in streams and rivers. E.g. Fontoura (1984) and Oliveira et al. (2001) found that the BBI discriminated polluted from reference sites at rivers in the North and Central Portugal respectively. In studies at rivers of Southern Portugal, Coimbra et al. (1996) and Coimbra \& Graça (1998) applied several biological metrics commonly used to assess water quality and concluded that, during summer, none of the tested methods was suitable for the local rivers, probably because of their marked Mediterranean hydrological regime. They suggested that multivariate analysis were a better alternative when measuring the impact of a known pollution source. Later, Graça \& Coimbra (1998) developed a new index in which takes account the specific local conditions of the Mediterranean Portuguese rivers.
It is therefore advisable to carry on studies to determine the applicability of indices commonly used in Europe to Portuguese specific conditions. On the other hand, it is also important to assess the sensibility of the indices to a large range of pollution sources.

Therefore, the general objective of the present research was to assess the suitability of the several available techniques to quantify the impact of a paper mill effluent in a small river in Central Portugal: S. João stream / Arouce river, Lousã.

\section{MATERIAL AND METHODS}

The S. João stream runs from Lousã Mountain to Lousã village, after which is known as Arouce river. Before entering in the village, it receives an effluent from a paper factory (Fig.1).

Macroinvertebrates were sampled in April and May of 1997 and 1998 respectively with a $1 \mathrm{~mm}$ mesh size sieve (approximately 20 minutes) mainly in riffles since these predominated along the studied area.

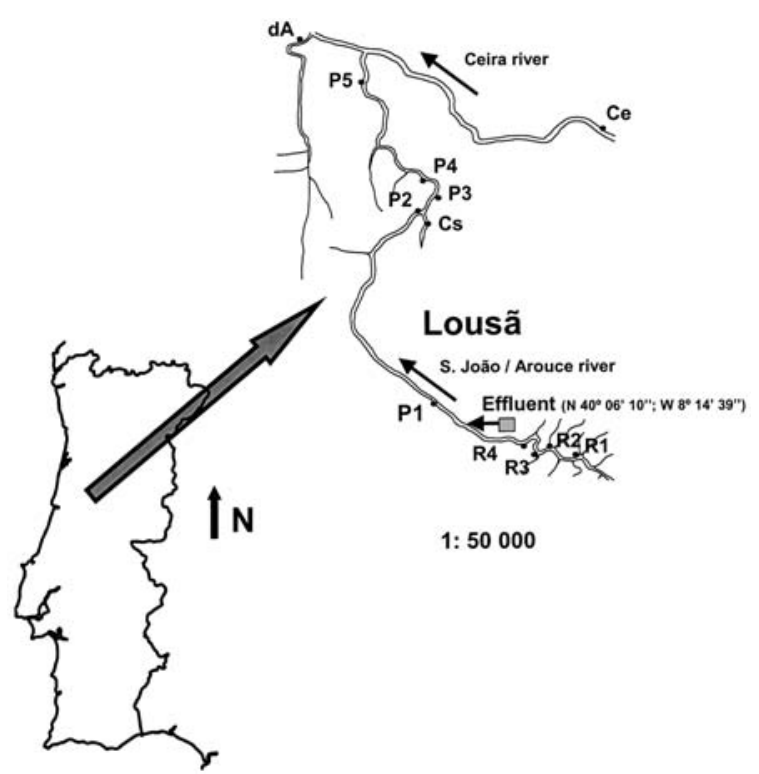

Figure 1. Sampling sites located in São João / Arouce stream and nearby rivers. Estaciones de muestreo localizadas en el arroyo São João / Arouce y ríos cercanos. 
Table 1. Physico-chemical parameters measured along the sampling sites located in S. João / Arouce river (May, 2000). Parámetros fisico-químicos medidos a lo largo de las estaciones de muestreo en el río São João / Arouce (Mayo de 2000).

\begin{tabular}{lccccccccc}
\hline & R1 & R2 & R3 & R4 & P1 & P2 & P3 & P4 & P5 \\
\hline Dissolved Oxygen $(\mathrm{mg} / \mathrm{L})$ & 10.2 & 10.2 & 10.1 & 10.0 & 0.6 & 0.7 & 7.4 & 6.7 & 9.5 \\
Temperature $\left({ }^{\circ} \mathrm{C}\right)$ & 14.5 & 14.5 & 14.7 & 14.8 & 18.5 & 18.8 & 16.0 & 15.0 & 16.3 \\
pH & n.m. & n.m. & n.m. & 7.0 & 7.4 & n.m. & 6.5 & 6.5 & n.m. \\
Conductivity $(\mu \mathrm{S} / \mathrm{cm})$ & n.m. & n.m. & n.m. & 57 & 50 & n.m. & 155 & 146 & n.m. \\
\hline
\end{tabular}

n.m. $=$ not measured

They were sampled again in May (a) and June (b) of 2000 with a $0.5 \mathrm{~mm}$ mesh size hand net in a kick and sweep way (standardised for 5 minutes).

In May of 2000, water temperature, dissolved oxygen, $\mathrm{pH}$ and conductivity were also measured in situ with portable oxygen-, $\mathrm{pH}$ - and conductivity meters. We sampled 12 sites including 5 downstream the effluent output (P1, P2, P3, P4 and P5), 3 sites in other nearby streams (Cs, Ce, and $\mathrm{dA}$ ), and 4 reference sites located upstream the effluent output (R1, R2, R3 and R4) (Fig. 1).

Macroinvertebrates were sorted alive both in the field and at the laboratory and preserved in $70 \%$ ethanol for further identification to genus or family levels, under a dissecting microscope. The macroinvertebrate data set was used to calculate the complementary of Simpson diversity index (Clarke \& Warwick, 2001), and was subjected to cluster and MDS analyses (log transformation data, Bray-Curtis similarity coefficient, PRIMER v5; Clarke \& Gorley, 2001) and to a correspondence analysis $(\mathrm{CA}$; $\ln$ transformation data, CANOCO 4; ter Braak \& Smilauer, 1998) to determine if changes in the environmental conditions affected invertebrate assemblages. The biological data was also used to calculate BMWP' and BBI scores. These values may not correspond to the BMWP' and $\mathrm{BBI}$ indices since the calculation was made "a posteriori" and the correct protocol was not followed (De Pauw \& Vanhooren, 1983; AlbaTercedor, 1996). Consistency between community structure and biotic indices was also investigated by correlation (Spearman coefficient) between the biotic indices values and the $1 \mathrm{st}$ two CA ordination axes. The site groups defined by cluster and MDS analyses were submitted to an analysis of similarity (ANOSIM; Clarke \& Warwick, 2001).

\section{RESULTS}

In May of 2000 the effluent caused a strong decrease in dissolved oxygen concentration: from $10.1 \pm 0.1 \mathrm{mg} / \mathrm{L}$ in reference sites $(n=4)$ to anoxia conditions $(0.6 \mathrm{mg} / \mathrm{L})$ in the vicinity of the effluent output (Table 1). Only after $7 \mathrm{~km}$ downstream (P5) there was a recovery to 9.5 $\mathrm{mg} / \mathrm{L}$. Water temperature, $\mathrm{pH}$ and conductivity were not so strongly affected by the effluent emission (Table 1).

A total of 60 taxa were sampled. At the reference sites, Plecoptera, Ephemeroptera and Trichoptera were the dominant groups. Immediately below the effluent discharge and until tributary $\mathrm{Cs}$ (at ca $4 \mathrm{~km}$ downstream) only larvae of Chironomidae were present. After the junction with tributary Cs there was an increase in number of taxa, especially in Baetis sp., Ephemerella sp., Hydropsyche sp. (P3, $4.5 \mathrm{~km}$ ) and Habrophlebia sp. (P4, $5 \mathrm{~km})$. At site P5 (7 $\mathrm{km}$ downstream the discharge; only sampled in May 2000) the number of taxa was again similar to the observed in the reference sites.

BMWP' and BBI as well as the diversity (measured both by number of taxa and 1Simpson index) (Table 2) showed a strong impact on the macroinvertebrate communities caused by the effluent emission. Despite of some differences, both biotic indexes revealed a good water quality in the reference area (R1R4) and very strong pollution conditions immediately downstream the effluent output 
Table 2. Diversity measurements: number of taxa (T) and complementary of Simpson index (1-?), and water quality measurements by BMWP' and BBI indices for the sites sampled along S. João / Arouce river: 97, 98, 00a and 00b represent the sampling years of 1997, 1998, May and June 2000, respectively. Medidas de diversidad: número de taxones (T) y complementario del indice de Simpson (1 - ?), y medidas de calidad del agua mediante los índices BMWP'y BBI para las estaciones muestreadas a lo largo del río S. João / Arouce: 97, 98, 00a y 00b representan los años de muestreo 1997, 1998, mayo y junio de 2000 respectivamente.

\begin{tabular}{|c|c|c|c|c|c|c|}
\hline Site & $\mathbf{T}$ & $1-\lambda$ & ВMWP' & BBI & BMWP' class & BBI class \\
\hline R100a & 27 & 0.903 & 156 & 10 & I & I \\
\hline R100b & 30 & 0.930 & 163 & 10 & I & I \\
\hline R198 & 21 & 0.915 & 130 & 10 & I & I \\
\hline R197 & 23 & 0.866 & 125 & 10 & I & I \\
\hline R200a & 33 & 0.923 & 188 & 10 & I & I \\
\hline R298 & 21 & 0.902 & 101 & 10 & I & I \\
\hline R297 & 20 & 0.845 & 94 & 10 & II & $\mathrm{I}$ \\
\hline R300a & 31 & 0.892 & 192 & 10 & I & I \\
\hline R398 & 19 & 0.847 & 97 & 10 & II & I \\
\hline R397 & 20 & 0.833 & 104 & 10 & $\mathrm{I}$ & I \\
\hline R400a & 22 & 0.884 & 122 & 10 & $\mathrm{I}$ & $\mathrm{I}$ \\
\hline R400b & 24 & 0.895 & 124 & 10 & I & I \\
\hline R498 & 19 & 0.865 & 89 & 10 & II & I \\
\hline R497 & 20 & 0.864 & 81 & 10 & II & I \\
\hline P100a & 2 & 0.600 & 5 & 2 & $\mathrm{~V}$ & $\mathrm{~V}$ \\
\hline P198 & 1 & 0.000 & 2 & 1 & $\mathrm{~V}$ & V \\
\hline P197 & 1 & 0.000 & 2 & 1 & $\mathrm{~V}$ & $\mathrm{~V}$ \\
\hline P200a & 5 & 0.365 & 7 & 2 & $\mathrm{~V}$ & $\mathrm{~V}$ \\
\hline P200b & 7 & 0.772 & 19 & 5 & IV & III \\
\hline P298 & 1 & 0.000 & 2 & 1 & $\mathrm{~V}$ & $\mathrm{~V}$ \\
\hline P297 & 1 & 0.000 & 2 & 1 & $\mathrm{~V}$ & $\mathrm{~V}$ \\
\hline P200a & 11 & 0.678 & 40 & 6 & III & III \\
\hline P398 & 8 & 0.776 & 24 & 5 & IV & III \\
\hline P397 & 9 & 0.760 & 28 & 5 & IV & III \\
\hline P400a & 15 & 0.772 & 71 & 8 & II & II \\
\hline P498 & 12 & 0.762 & 48 & 7 & III & II \\
\hline P497 & 18 & 0.859 & 115 & 9 & I & I \\
\hline P500a & 22 & 0.772 & 132 & 9 & I & I \\
\hline $\mathrm{Cs} 00 \mathrm{a}$ & 17 & 0.878 & 105 & 9 & I & I \\
\hline $\mathrm{Cs} 98$ & 18 & 0.873 & 97 & 9 & II & I \\
\hline Cs97 & 18 & 0.870 & 101 & 9 & I & I \\
\hline $\mathrm{CeO0a}$ & 14 & 0.912 & 59 & 7 & III & II \\
\hline
\end{tabular}

until tributary Cs (Table 2). After this tributary these indices showed a gradual recovery in terms of water quality (sites P3-P5; $4-7 \mathrm{~km}$ ). However, in 2000 the indices values were higher than the values calculated for 1997 and 1998. This was true for both indices for the sites located downstream the effluent output and for BMWP' values of the reference sites (Table 2). Comparing also classes of water quality, calculated by both indices, it is possible to detected differences of 1 class in 10 cases including 3 reference (1 in two sampling occasions) and 5 downstream sites (2 in two different periods). In this case BMWP' showed always the lower class of quality (Table 2 ).

Cluster analysis defined 5 major groups (Fig. 2A): group $\mathrm{A}-$ all reference sites, all dates, group $\mathrm{B}$ - downstream sites, group $\mathrm{C}-$ site $\mathrm{Cs}$ (all dates), group D - further downstream sites and sites located in nearby streams and group E - strongly polluted sites P1 and P2. This pattern shows that macroinvertebrate communities were 


\section{A) Cluster Analysis}

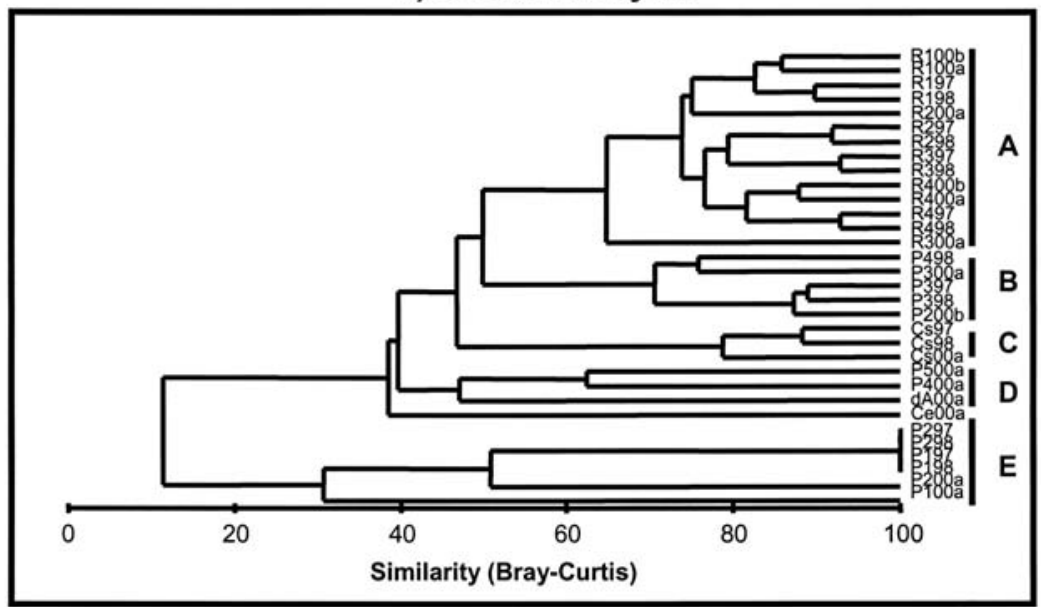

B) MDS Analysis

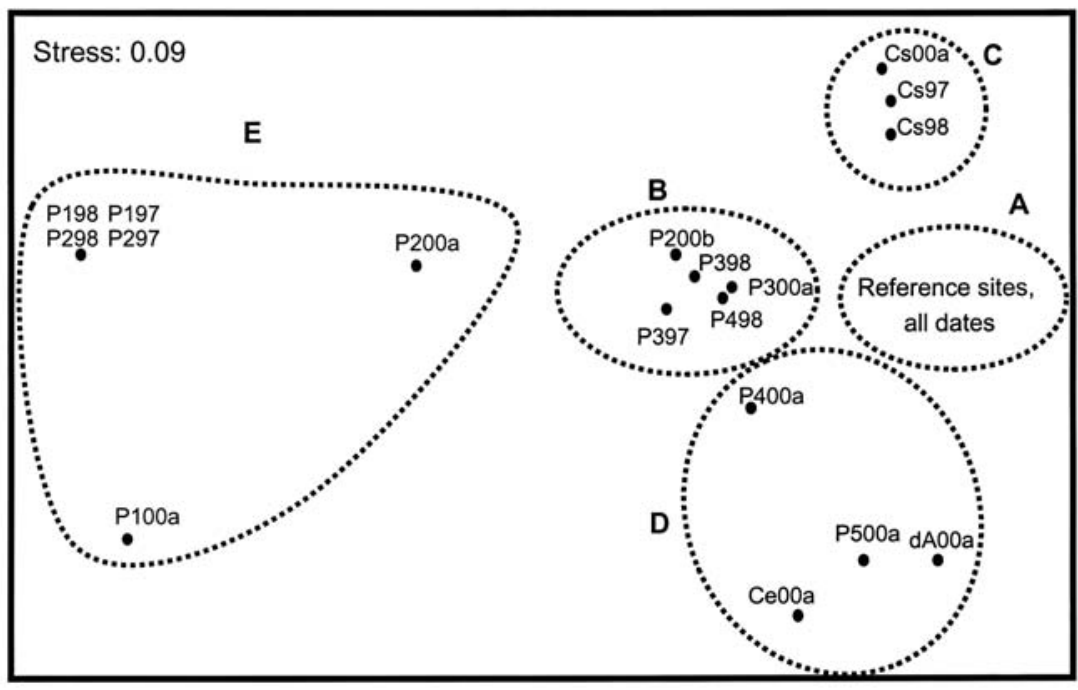

Figure 2. Cluster (A) and MDS (B) analyses of macroinvertebrate data sampled along the S. João / Arouce stream; 97, 98, 00a and 00b represent the sampling years 1997, 1998, May 2000 and June 2000 respectively. Análisis cluster (A) y MDS (B) de los datos de macroinvertebrados muestreados a lo largo del arroyo São João / Arouce; 97, 98, 00a y $00 \mathrm{~b}$ representan los años de muestreo 1997, 1998, mayo de 2000 y junio de 2000 respectivamente.

strongly affected by the effluent emission and that there was a gradual but not complete recovery downstream in terms of composition (further downstream sites were not clustered with reference sites). MDS (Fig.2 B) and CA (diagram not showed) analyses were consistent with cluster analysis: segregation between reference sites and polluted sites. Differences in terms of similarity among the 5 groups were highly sig- nificant (ANOSIM procedure; $\mathrm{R}$ global $=0.936$; $\mathrm{P}<0.001)$. The first axis resulting from $\mathrm{CA}$ analysis showed a pollution gradient $\left(1^{\text {st }}\right.$ axis eigenvalue and percentage of total explanation were 0.371 and $17.1 \%$ respectively; sum of all eigenvalues $=2.170)$. The correlation (Spearman coefficient) between BBI and BMWP' values with this CA first axis was highly significant $\left(\mathrm{r}_{\mathrm{s}}=0.778\right.$ and 0.738 respec- 
tively, $\mathrm{P}<0.001, \mathrm{n}=32$ ). Both indices showed also a high and significant correlation with the two structural parameters diversity (complementary of Simpson index) and number of taxa $\left(\mathrm{r}_{\mathrm{s}}>0.790, \mathrm{P}<0.001, \mathrm{n}=32\right)$. This shows a strong consistency between changes in macroinvertebrate community structure and the water quality classification by the biotic indices.

\section{DISCUSSION}

The source of S. João / Arouce river is located in Lousã Mountain and runs under minimal perturbation conditions until entering the village of Lousã. The first important stress is the use of water for paper production with a subsequent effluent discharge into the river. One of the main effects of the effluent discharge is a strong decrease in dissolved oxygen, which causes a very low water quality lasting for $4 \mathrm{~km}$ downstream. One of the main biological effects of the effluent input was the replacement of a diverse community of macroinvertebrates by a single taxon for the next $4 \mathrm{~km}$ : larvae of red Chironomidae. This replacement was also reported in the literature in situations of strong organic pollution where decreases in dissolved oxygen have been observed (e.g. Paine \& Gaufin, 1956). The decrease in dissolved oxygen can be explained by the organic addition into the river of the effluent and its chemical oxygen consumption.

Changes in community structure, measured by the application of multivariate techniques were consistent with the measurements of the biotic indices and diversity measurements. Other studies had showed a good correlation between the score of biotic indices and physicochemical parameters and the changes in the structure of aquatic communities (e.g. ZamoraMuñoz et al., 1995; Zamora-Muñoz \& AlbaTercedor 1996). If the performance of a biotic index is confirmed with the abiotic information and by multivariate methods analysing community structure, why do not use directly this method? Firstly, measuring biota itself is more relevant than measuring the abiotic conditions.
Secondly, the application of biotic indices is much easier than the multivariate analysis. However, biotic indices should only be applied if their performance to assessing a large variety of stressing conditions is studied.

In this study the values of both biotic indexes were always higher in 2000 than in 1997 and 1998 for sites located downstream the effluent output. For reference sites, only BMWP' showed higher values in 2000, when comparing them with the other two sampling years. These differences could be explained by a) the use of a finer mesh size in 2000 , b) a real improvement in water quality in 2000 or c) both reasons. Since the indices were calculated from a database designed to assess differences in invertebrate assemblages, the sampling design did not followed the original protocols. This was obvious for BMWP' calculations in 1998 and 1997 when was used only a $1 \mathrm{~mm}$ sieve and sampled mainly riffle habitat by time. In spite of the effort to collect a representative sample of each site (5 and 20 minutes sampling time until no new taxa were found by naked eye), this could not be enough to avoid underestimation of the indices' values. The performance of both indexes was similar in most of the cases. However, in sites and occasions where the water quality classes calculated for each index were different, BMWP' showed always the lower value. This may show that BMWP' was more conservative than BBI but also that the former was more affected by the sampling methodology than the latter. This emphasises the need for the use of the correct sampling protocol for the application of each biotic index to avoid misinterpretations. Despite these limitations, the biotic indices' values and water quality classes were consistent with changes in community structure (multivariate analyses, diversity and number of taxa). However, BMWP' is easier to apply and requires also less taxonomic expertise than BBI. Coimbra et al. (1996) and Coimbra \& Graça (1998) reported that the BMWP' and BBI are highly dependent on the seasonal hydrological regime. However, these works referred to an intermittent river in 
South Portugal. In regions where this seasonality is less strong, as in this case of the studied stream system in Central Portugal, the BMWP' seems to perform well (e.g. Oliveira et al., 2001, Graça et al., 2002, Ferreira et al., 2004).

This research and most of the cited references analysed situations of point source pollution. Therefore there is a need for documentation of diffuse pollution, which is, in general, more difficult to assess. Another practical aspect of the use of biotic indices is their sensitivity to slight pollution. For practical reasons many studies have been carried out in areas suffering from strong pollution. However, much more difficult to assess is the stress caused by slight increases in nutrients and pollutants in the waters. Therefore, the needs now are to assess the threshold of biotic indices to assess pollution effects.

\section{ACKNOWLEDGMENTS}

We thank to an anonymous referee for critical comments on the manuscript.

\section{REFERENCES}

ALBA-TERCEDOR, J. \& A. SÁNCHEZ-ORTEGA. 1988. Un método rápido y simple para evaluar la calidad biológica de las aguas corrientes basado en el de Hellawell (1978). Limnetica, 4: 51-56.

ALBA-TERCEDOR, J. 1996. Macroinvertebrados acuaticos y calidad de las aguas de los rios. IV SIAGA, Almeria, España: 203-213.

ARMITAGE, P. D., D. MOSS, J. F. WRIGHT \& M. T. FURSE. 1983. The performance of a new biological water quality score system based on macroinvertebrates over a wide range of unpolluted running-water sites. Water Research, 17: 383-347.

CLARKE, K. R. \& R. M. WARWICK. 2001. Change in Marine Communities. An approach to statistical analysis and interpretation. $2^{\text {nd }}$ edition. PRIMER-E Ltd. Plymouth.

CLARKE, K. R. \& R. N. GORLEY. 2001. PRIMER v5: User Manual / Tutorial. PRIMER-E Ltd. Plymouth.

COIMBRA, C. N. \& M. A. S. GRAÇA. 1998. Water quality assessment based on macroinvertebrate community struture: a comparison between methods. Verh. Internat. Verein. Limnol., 26: 2362-2366.

COIMBRA,C. N., M. A. S. GRAÇA \& R. M. CORTES. 1996. The effects of a basic effluent on macroinvertebrate community structure in a temporary Maditerranean river. Environmental Pollution, 94: 301-307.

DE PAWN, N. \& G. VANHOOREN. 1983. Method for biological quality assessment of watercourses in Belgium. Hydrobiologia, 100: 152-168.

FERREIRA, V., M. A. S. GRAÇA, M. J. FEIO \& C. MIEIRO. 2004. Water quality cartography in the Mondego river basin: pollution and habitat heterogeneity. Limnetica, 23(3-4): 295-306.

FONTOURA, A. P. 1984. Les communautés de macro-invertebrés du bassin hydrographique du fleuve Lima comme indicateurs de la qualité biologique de l'eau. Publicaçöes do Instituto Dr.Augusto Nobre, 183: 1-20.

GARCIA-CRIADO, F., A. TOME, F. J. VEGA \& C. ANTOLIN. 1999. Performance of some diversity and biotic indices in rivers affected by coal mining in northwestern Spain. Hydrobiologia, 394: 209217.

GRAÇA, M. A. S \& C. N. COIMBRA. 1998. The elaboration of indices to assess biological water quality. A case study. Water Research, 32: 380392.

GRAÇA, M. A. S., C. N. COIMBRA, M. J. CARVALHO, R. OLIVEIRA \& M. ABELHO. 2002. Freshwater macroinvertebrates in the Mondego river basin. In: Aquatic Ecology of the Mondego River Basin. Global importance of local experience. M.A. Pardal, J.C. Marques \& M.A. Graça (eds): 115-124. Imprensa da Universidade de Coimbra, Coimbra.

HELLAWELL, J. M. 1986. Biological indicators of freshwater pollution and environmental management. Elsevier Applied Science Publishers Ltd. Essex.

METCALFE, J. L. 1989. Biological water quality assessment of running waters based on macroinvertebrate communities: history and present status in Europe. Environmental Pollution, 139: 60-101.

METCALFE-SMITH, J. L. 1996. Biological waterquality assessment of rivers: use of macroinvertebrate communities. In: The Rivers Handbook. Hydrological and ecological principles. Volume 1. P. Calow \& G. E. Petts (eds.): 144-170. Blackwell Science Ltd. Oxford. 
OLIVEIRA, R. L., M. A. S. GRAÇA \& C. N. COIMBRA. 2001. Cartografia da qualidade da água em alguns sectores da bacia hidrográfica do Rio Mondego (com base em macroinvertebrados). Actas da VII Conferência Nacional sobre a Qualidade do Ambiente, Aveiro, Portugal: 580-584.

PAINE, Jr, G. H. \& A. R. GAUFIN. 1956. Aquatic diptera as indicators of pollution in a Midwestern stream. The Ohio Journal of Science, 56: 291-301.

ter BRAAK, C. J. F. \& P. SMILAUER. 1998. CANOCO Reference Manual and User's Guide to Canoco for Windows: Software for Canonical Community Ordination (version 4). Microcomputer Power. Ithaca, NY, USA. 352pp.

VERNAUX, J., P. GALMICHE, F. JANIER \& A. MONNOT. 1982. Une nouvelle method pratique d'évaluation de laqualité des eaux courantes. Un indice de qualité biologique génerale (I.B.G.). Ann. Sci. Univ. Besançon, Biol. Anim.. 4ème sér. 3: 11-21.
WATER FRAMEWORK DIRECTIVE. 2000. Directive 2000/60/EC of the European Parliament and of the Council of 23 October 2000 establishing a framework for Community action in the field of water policy. Official Journal of the European Communities. 22/12/2000. L 327/1-72.

WOODIWISS, F. S. 1964. A biological system to stream classification used by Trent River Board. Chemy. Ind., 11: 443-447.

ZAMORA-MUÑOZ, C., C. E. SÁINZ-CANTERO, A. SÁNCHEZ-ORTEGA \& J. ALBA-TERCEDOR. 1995. Are biological indices BMWP' and ASPT' and their significance regarding water quality seasonally dependent? Factors explaining their variations. Water Research, 29: 285-290.

ZAMORA-MUÑOZ, C. \& J. ALBA-TERCEDOR. 1996. Bioassessment of organically Spanish rivers, using a biotic index and multivariate methods. J. N. Am. Benthol. Soc., 15: 332-352. 